\title{
Den menneskelige plet
}

Stefan Kjerkegaard: Den menneskelige plet. Medialiseringen aflitteratursystemet. Dansklærerforeningens Forlag 2017, 160 sider, 199 kr.

Hvordan kan og bør dansklærerne i gymnasierne på adækvat måde tage livtag med digtværker som YAHYA HASSAN (2013) og Asta Olivia Nordenhofs det nemme og det ensomme (2013)? Hvis vi sætter som præmis, at digitale teknologier og de sociale medier på afgørende måde har ændret betingelserne for de måder, hvorpå vi som subjekter dannes og kommunikerer, så kan man argumentere for, at overleverede tekstanalytiske tilgange og antagelser ( $\mathrm{fx}$ troen på det litterære værk som autonomt og helt, og subjektet som selvidentisk og selvberoende) er utilstrækkelige. Når vi samtidig med stor vedholdenhed nødes til at forholde os til spørgsmål om det private og det selvbiografiske hos fx digterne Bjørn Rasmussen og samme Hassan og Nordenhof, og lidt før hos en Claus Beck-Nielsen og en Karl Ove Knausgård, tegner der sig nødvendigheden af at revidere det metodiske og teoretiske beredskab. Stefan Kjerkegaards Den menneskelige plet udgør et i mange henseender prisværdigt, men ikke helt igennem uproblematisk forsøg på først at diagnosticere og dernæst opdatere den angiveligt noget gammeldags måde at bedrive tekstanalyse på i gymnasiet, når det gælder medialiseret samtidslitteratur, samtidig med at Kjerkegaard mere alment slår til lyd for en ny og mere præcis forståelse af, hvad der er på spil i og med denne type litteratur.

Kjerkegaards tekst er omkranset af en Introduktion (der ridser felt og ærinde op) og en Afslutning (der leverer et eksempel på en neo-menneskelig læsning af Nordenhofs digte), hvorimellem seks kapitler analyserer henholdsvis Hassan, identitetspolitik og "minoritetsagency" (kapitel 1), litteratur som "iværksættelse" indlejret i "medialisering" (kapitel 2), parateksternes rolle i en medialiseret læsning af litterære figurer som Hassan og Beck-Nielsen (kapitel 3), hele det problembundt der knytter sig til de langtfra synonyme termer selvbiografi, autofiktion og performativ biografisme (kapitel 4), et eksempel på en eksemplarisk "kontekstuel" læsning af YAHYA HASSAN (kapitel 5), og endelig en undersøgelse af det "private" i det Kjerkegaard foreslår at kalde en "performativ privatisme" (kapitel 6).

Påstandene og hypoteserne er mange, men grundlæggende kan man sige, at Kjerkegaards forehavende hviler på et ganske bastant norm-nybrud skema. Før de nye medier og nettets opkomst var vi alle en art nykritikere, der troede, at litteraturen og subjektet begge var autonome størrelser. Efter samtidslitteraturen, og Kjerkegaards nye værk, blev vi imidlertid klar over, at den nye litteratur er radikalt heteronom, og at subjektet er sårbart, indlagt i et positioneringsspil og underlagt medieteknologiernes vilkår. Indenfor rammerne af denne heteronomi og sårbarhed kan vi dog etablere forskellige former for modstand eller "resistens", som Kjerkegaard interessant nok kalder det (s. 31, 120, 123), og modeller for en sådan modstand kan vi finde frapperende eksempler på i dansk samtidslitteratur. Nu er jeg tæt på at ironisere, men det er jeg kun, fordi Kjerkegaard flere steder (fx s. 30, 42-43, 49, 137) kommer for tæt på at fremstille normen reduktivt, ahistorisk og fortegnet, oftest som et spørgsmål om at "nykritikken" og "modernismen" (begge i bestemt ental) knæsatte problematiske autonomi-kulturer, som vi nu gudskelov 
kan frigøre os fra. Sine steder får Kjerkegaard det næsten til at se ud, som om det samlede "litteratursystem" (en term der er dejligt ubelastet af at have konsulteret Kittler eller Luhmann) stadig hænger fast i Brostrøms modernismeforståelse og Fjord Jensens nykritik anno 1965.

Og det er jo dog nok en svag fortegnelse - tilgivelig, måske, al den stund det tjener til at fremhæve det nybrydende ved den medialiserede samtidslitteratur, Kjerkegaard kerer sig om og her hævder adækvat at fremstille. Kjerkegaard synes lidt vagt at abonnere på en forståelse af Lyotard og Fukyama (s. 11), der siger, at de store fortællingers tid er slut og afløst af en epoke, hvor vi "fortløbende er fortællere i vores eget liv" (s. 11). Kjerkegaard ved selvfølgelig godt, at det er en langt ældre og mere kompleks historie (Augustin var vist nok ret bevidst om selvfortællingens kår), men har - det er banalt sandt - ret i, at de sociale medier har intensiveret og demokratiseret adgangen til og betingelserne for selvfremstilling.

Det er på den ene side en mulighed, på den anden side er det et ubønhørligt pres; vi skal fortælle os selv, der er en interpellerende fortællepligt, og fortællingen skal være herlig og konsistent 24-7. Kjerkegaard fremfører nu, at det vi kan finde hos fx Caspar Eric og Nordenhof, er en art litterær oprigtighed og ærlighed; en oprigtighed, der imidlertid kun kan fejle i den medialiserede mediering af ordene; denne fejlen giver ophav til en usikkerhed og sårbarhed, der "danner ramme om det, jeg kalder den menneskelige plet, og den er i mine øjne det vigtigste kendemærke ved den nye danske litteratur” (s. 19). Pletten er ikke en uheldig blottelse, men en "bevidst de-autonomisering og etisk handling i og med litteraturen: en menneskelig henvendelse inkorporeret i det, som litteraturen gør, snarere end i det, den siger" (s. 19). Hvori består denne lutrende gøren? Det kan vi ifølge Kjerkegaard bedst indfange med termerne iværksættelse og intervention. Baseret på den præmis, at litteratur også er interaktiv retorik og kommunikation (s. 34 bliver det til en lidt kedelig wishy-washy påstand om, at litteratur både er kommunikation, og at der findes særlige træk ved litteraturen), søger Kjerkegaard i kapitel 2 at give en lidt nærmere bestemmelse af "iværksættelse" og "intervention".

Iværksættelse betegner for Kjerkegaard dels et nøje blik på litteraturens materialitet, de mangfoldige måder hvorpå en bogs fysiske fremtoning er en iboende del af dens iværksættelse (et eksempel er Johannes Heldéns digitale værk Evolution, men i kapitel 3 angår det tillige de genetteske parateksters rolle), dels litteraturens indlejring i det der efter Stig Hjarvad kaldes for "medialisering": "medialiseringen synliggør kunstarten litteraturs medialitet, dvs. litteraturens måde at være et medie på" (s. 67). Den litterære medialitet er "en proces, der fortæller os, at litteratur også må forstås uafhængigt af det tekniske medie, som den konventionelt oftest har optrådt i forbindelse med, dvs. bogen" (s. 67). Litteraturen er både værk og udenomsværker. Det sidste aspekt åbner for "intervention", dvs. alle de måder hvorpå litteraturen og forfatteren kan siges at virke gennem, men i høj grad også uden for bogens strikte rammer. Det sidste skildrer Kjerkegaard fint $i$ et af sin bogs bedste kapitler, nemlig kapitel 3 om parateksterne, der udmunder i et hastigt blik på Claus Beck-Nielsen og Yahya Hassan. Dog en anke: "intervention" forudsætter implicit to strikt adskilte domæner - litteraturens og verdens. Idet Kjerkegaard vil opbløde grænsen mellem de to domæner eller plæderer for, at en "transaktionszone" mellem dem forhandles hos fx Beck-Nielsen, kommer han da ikke til for reduktivt at knæsætte den grænse, han gerne vil se udvisket? Og er dette problem ikke afledt af, at han 
aldrig mere præcist får bestemt, hvad der menes med "litteratursystemet", men forlader sig på en såkaldt "pragmatisk" forståelse af, at det er forlagene, aviserne, universiteterne, forfatterskolerne (jf. s. 9) etc.?

Det er ikke kun forfatterne, der skal positionere og differentiere sig på et medialiseret marked. Det skal Kjerkegaard også - og det ser man tydeligst i omgangen med rivaler og kolleger som Tue Andersen Nexøs Vidnesbyrd fra velfærdsstaten (2016), Behrendts Dobbeltkontrakten (2006) og Helt Haarders Performativ biografisme (2014). Er hele feltet ikke allerede udmærket behandlet i de tre forgængerværker? Kjerkegaard mener nej, lidet overraskende. Venligt, men bestemt, insisterer han på, at Nexø er lidt for gammeldaws (s. 128), og at hverken Haarder eller Behrendt helt rammer det, han selv sigter efter. Det sker dels i form af en udmærket undvigelse af alle de kedelige diskussioner (begrebsafklaringer, fiktion vs. ikke-fiktion), dels en udmærket sondring (performativ biografisme er en isme, autofiktionen er en genrebetegnelse, og dobbeltkontrakten er en læsemåde, alle s. 84) - og dels endelig i en påstand om, at selve spørgsmålet om identitet her er kernen. Ved at gribe tilbage til gamle Philippe Lejeune og dernæst give et udmærket rids over nyere autofiktioner i Skandinavien, opstiller Kjerkegaard to mulige analytiske forholdelsesmåder over for autofiktionen: enten at forlade den nærlæsende værklæsning og medtage kontekster og paratekster eller "give efter for værkets eksistentielle appel, læse det affektivt så at sige og tage hensyn til den måde, man som læser faktisk knytter sig til værket på" (s. 102). Det første gør Kjerkegaard i kapitel 5, overfor YAHYA HASSAN, det sidste gør han i Afslutningen, overfor Nordenhofs det nemme og det ensomme.

Lad gå, at Kjerkegaard øjensynligt aldrig rigtig forstår, hvad affektteori går ud på (det er sigende, at han citerer Sianne Ngai og Butler, som heller aldrig skelner mellem følelser og affekter, men ikke besøger fx Guattari eller Massumi), og typisk benytter "følelser", "emotioner" og "affekter" som synonyme termer, men det virkeligt slående er, at Hassanlæsningen er rigtig god, mens Nordenhof-læsningen bliver underligt kvalmt indsmigrende og uklar. Årsagen til dette er vigtig at berøre.

Jeg mistænker, at en sympatisk krypto-gammelhumanisme og vagt politisk streng løber gennem Kjerkegaards værk, som en lidt akavet, menneskelig plet. Kjerkegaard har læst Hjarvad, men tydeligvis ikke Yuval Noah Harari, den israelske historiker, der i fx Homo Deus (2015) indgående skitserer fremkomsten af helt nye, bioteknologisk sofistikerede og posthumane mennesketyper om ganske kort tid. Set i det lys er der noget næsten rørende ved Kjerkegaards nationalt fikserede og antropocentriske optagethed af det sårbare og det usikre hos en lille flok danske digtere i begyndelsen af det enogtyvende århundrede. I et blik på det privates litterære egenart hos Nordenhof, konkret i en enkelt statusopdatering på Facebook 21-22/6 2016, bemærker Kjerkegaard, at "det i dag er det offentlige, som berøver os noget som individer" (s. 133). Næste side lyder det bifaldende om Nikolaj Zeuthen, at "[o]gså han ønsker at give forfatteren sin autoritet og subjektivitet tilbage". Og i den afsluttende læsning af Nordenhof lyder det med patos: "At blotte sig er en etik i øjenhøjde med verden" (s. 147). Samme sted: "Vi er alle udsatte. Derfor også ideen om, at verden er der før os, ikke for os" (s. 147). Ja, vi er alle udsatte på hjertets bjerge, men dette er altså ikke ligefrem Heidegger eller en avanceret, medieteknologisk bevidst tekstanalyse af Nordenhofs digt. Jeg kan virkelig godt lide, at Kjerkegaard før denne Nordenhof-eskapade inddrager Lionel Trillings 1972-værk Sincerity and Authenticity, men der er altså sine steder i dette værk en uheldig tendens til det, Adorno i anden 
sammenhæng kaldte for egentlighedens jargon. Analytisk kan det lyde som fx "eksistentiel appel”, stilistisk ytrer det sig bl.a. som små tics, fx: "Der er måske så meget pis, både i verden og i tekster, kunne man mene” (s. 142). Tjo. Men man kan også læse sådanne lidt kiksede indbrud af talesprog som et symptom på en anfægtet og bekymret gammelhumanisme, der dels gerne vil afvige fra lektorfunktionærens standardprosa, dels derved vil lade Livet bryde ind i teksten. Så er Kjerkegaard betydeligt mere præcis og nøgtern i sin analyse af Yahya Hassans værk og iværksættelse af en medialiseret subjektivitet, i kapitel 5.

Alle, der har erfaring med at undervise i litteraturteori ved, at man kan pille enhver tekst fra hinanden. Man kan også altid lave en stråmand, dvs. fermt fortegne og karikere tekstens egentlige udsagn, i stedet for på redelig vis at gengive argumentet, lytte og replicere. Ingen af tilgangene forekommer at være synderligt frugtbare i en anmeldelse. Men der er dog et antal indvendinger og spørgsmål, jeg i det mindste vil nævne.

For det første, at hele det underligt forsinkede opgør med nykritikken og alt det angiveligt tilknyttede på en besynderlig måde overser den historiske avantgardes rolle - her har vi jo netop afvisningen af værkbegrebet, emfasen på heteronomi, legen med fragmenteret subjektivitet, udforskningen af paratekstuelle og typografiske virkemidler etc. Skyldes denne forglemmelse, at Kjerkegaard (der jo kender sin Højholt godt) underneden abonnerer på en sen variant af avantgardens æstetiske program? Eller kunne det omvendt tænkes, at den medialiserede litteratur på afgørende måder realiserer nogle af den historiske avantgardes utopiske drømme? Og hvis det er tilfældet, hvorfor så ikke artikulere og reflektere over denne forbindelse?

I samme register: Kjerkegaard benytter adskillige gange ordet "resistens" som navn for den gode litteraturs modstandspotentiale og et andet sted "osmose" (navnet på den proces, der finder sted, idet væsker siver ind og ud gennem fx en cellemembran) - men det er da en anelse pudsigt, fordi disse påfaldende organiske metaforer knytter ganske direkte an til den nykritik, der sættes som træsk modstander og modnorm? Og desuden har dybe rødder ned i en romantisk metafysik, der tænker værket som sund krop. Ikke alene synes Kjerkegaard altså at reproducere sin postulerede modparts metaforik, men særligt ordet "resistens" synes at antyde en ikke uproblematisk, idealistisk tangent i værket; måske en krypto-romantisk tro på, at kunstens sunde antilegeme kan kæmpe imod den forvaltede verdens inficering af livsverdenen. I tilknytning hertil definerer Kjerkegaard aldrig sin brug af termen "etik", der således fremstår symptomatisk uklar.

Endvidere: Det er slående, at en uhyre gammeldags mimesis-tangent spøger gennem hele teksten; det hedder adskillige steder (fx s. 84), at verden har ændret sig, og at dette "afspejles" i litteraturen - men negerer en sådan mimetisk forståelse ikke den mere komplekse afdækning af litteraturens paratekstuelle transaktionszoner? Hænger Kjerkegaard ikke dermed halvvejs fast i en klassisk, mimetisk repræsentationsteori?

Hvad angår værkets teoretiske armatur, kunne djævlens advokat spørge sådan her: Er dette ikke blot et rehash af standard Cultural Studies, med et skvæt Butler og Derrida og en opdateret Sarah Ahmed (men hvor især Rancière har forputtet sig), koblet med lidt narratologi via Genette? Og hvis ja, hvori består da den store metodiske og teoretiske fornyelse?

Til slut et muligvis uretfærdigt hjertesuk: Hvorfor den så utroligt snævre fokusering på dansk, til nød nordisk samtidslitteratur? Desto mere påfaldende, som alle de inddragne forfattere er intenst påvirket af allehånde ikke-danske forfattere, som fx Duras, Ken- 
neth Goldsmith, Barthes, Juliana Spahr, Gertrude Stein, Lydia Davis osv. Svaret er banalt indlysende. Kjerkegaard er lektor på Nordisk på Aarhus Universitet, det er nu en gang fagets territorium og genstandsfelt. Men når nu de sociale medier og digitale teknologier er så intenst transnationale, når det litterære fænomen, der studeres er så globaliseret og ikke-provinsielt, og når verdenslitteratur som metodisk tilgang står så stærkt - hvorfor da ikke benytte lejligheden til at lave en halv Georg Brandes og gå videre endnu i studiet af den globale, menneskelige plet? Det var Emily Apter fra NYU, der for få år siden slog til lyd for at "deprovinsialisere kanon" - den bestræbelse ville nok med fordel kunne udfoldes i kommende studier af den medialiserede, menneskelige plet.

Sætter vi et øjeblik parentes om nogle af de indvendinger, man kan gøre gældende mod Den menneskelige plet, er det dog på samme tid et begavet, vigtigt og interessant værk, der i bedste fald vil skubbe os alle hen mod en mere forfinet og præcis forståelse af enkelte af de litterære implikationer af nogle teknologiske og sociale forandringer, der endnu kun er i deres vorden. Kjerkegaard anfører i begyndelsen at: “Tekst og kontekst forbinder sig via nye medier på en måde, som vi endnu ikke er i stand til at begribe konsekvenserne af" (s. 23). Her taler en sympatisk beskedenhed, og her taler Kjerkegaard ind i et enormt vakuum, som det til dels lykkes for ham at belyse. Jeg var undervejs irriteret og anfægtet - men jeg var aldrig i tvivl om, at Den menneskelige plet er et både tiltalende og oplysende værk, der i nogle henseender vil kunne gøre god nytte.

Anmeldt af Mikkel Bruun Zangenberg 